\title{
Activated Transcription Factor Nuclear Factor-Kappa B Is Present in the Atherosclerotic Lesion
}

\author{
Korbinian Brand, ${ }^{\star}$ Sharon Page, ${ }^{\star}$ Gerhard Rogler, ${ }^{\S}$ Armin Bartsch,, Richard Brandl,, Ruth Knuechel, $\|$ Michael Page,, \\ Christian Kaltschmidt," Patrick A. Baeuerle," and Dieter Neumeier* \\ *Institute of Clinical Chemistry and Pathobiochemistry, and ${ }^{\ddagger}$ Department of Vascular Surgery, Technical University Munich, D-81675 \\ München; ${ }^{\S}$ Department of Internal Medicine I and $\|^{\| n s t i t u t e ~ o f ~ P a t h o l o g y, ~ U n i v e r s i t y ~ o f ~ R e g e n s b u r g, ~ D-93042 ~ R e g e n s b u r g ; ~ a n d ~ " I n s t i t u t e ~}$ \\ of Biochemistry, Albert-Ludwigs-University Freiburg, D-79104 Freiburg im Breisgau, Germany
}

\begin{abstract}
Nuclear factor-kappa B (NF-кB)/Rel transcription factors play an important role in the inducible regulation of a variety of genes involved in the inflammatory and proliferative responses of cells. The present study was designed to elucidate the implication of $N F-\kappa B / R e l$ in the pathogenesis of atherosclerosis. Activation of the dimeric NF- $\mathrm{B}$ complex is regulated at a posttranslational level and requires the release of the inhibitor protein IкB. The newly developed $\mathrm{mAb} \alpha-\mathrm{p} 65 \mathrm{mAb}$ recognizes the IкB binding region on the p65 (RelA) DNA binding subunit and therefore selectively reacts with p65 in activated NF- $\kappa$ B. Using immunofluorescence and immunohistochemical techniques, activated NF$\kappa \mathrm{B}$ was detected in the fibrotic-thickened intima/media and atheromatous areas of the atherosclerotic lesion. Activation of NF- $\kappa \mathrm{B}$ was identified in smooth muscle cells, macrophages, and endothelial cells. Little or no activated NF-кB was detected in vessels lacking atherosclerosis. Electrophoretic mobility shift assays and colocalization of activated $\mathrm{NF}-\kappa \mathrm{B}$ with $\mathrm{NF}-\kappa \mathrm{B}$ target gene expression suggest functional implications for this transcription factor in the atherosclerotic lesion. This study demonstrates the presence of activated NF- $\kappa \mathrm{B}$ in human atherosclerotic tissue for the first time. Atherosclerosis, characterized by features of chronic inflammation and proliferative processes, may be a paradigm for the involvement of $\mathrm{NF}-\kappa \mathrm{B} / \mathrm{Rel}$ in chronic inflammatory disease. (J. Clin. Invest. 1996. 97:1715-1722.) Key words: smooth muscle cells • macrophages • endothelial cells $\bullet$ p65 $\bullet$ IкB
\end{abstract}

\section{Introduction}

Transcription factors of the nuclear factor-kappa B $(\mathrm{NF}-\kappa \mathrm{B})^{1 /}$ Rel family form dimeric complexes which inducibly control the expression of a plethora of genes involved in inflammation and proliferation $(1,2)$. The prototypic NF-кB dimer consists

Address correspondence to Dr. Korbinian Brand, Institute of Clinical Chemistry and Pathobiochemistry, Technical University Munich, Klinikum rechts der Isar, Ismaninger Str. 22, D-81675 München, Germany. Phone: 089-4140-4084 (4750); FAX: 089-4140-4875. Patrick A. Baeuerle's present address is Tularik Inc., 270 East Grand Avenue, South San Francisco, CA 94080.

Received for publication 23 June 1995 and accepted in revised form 19 January 1996.

J. Clin. Invest.

(C) The American Society for Clinical Investigation, Inc.

0021-9738/96/04/1715/08 \$2.00

Volume 97, Number 7, April 1996, 1715-1722 of the subunits p50 and p65 (RelA), although other complexes have been described $(3,4)$. In the inactive state the NF-кB dimer is present in the cytosol bound to an inhibitory protein, IкB $(5,6)$. Activation of NF-кB by a multitude of stimuli, including inflammatory cytokines, reactive oxygen intermediates, and microorganisms requires the release of the inhibitor I $\kappa$ B from the dimeric complex (3-7). This is followed by an immediate translocation of activated $\mathrm{NF}-\kappa \mathrm{B}$ to the nucleus where the dimer interacts with regulatory $\kappa \mathrm{B}$ elements in promoters and enhancers, thereby controlling gene transcription $(3,4,7)$.

Several lines of evidence indicate that NF-кB/Rel transcription factors may play an important role in atherosclerosis (8-11). Activation of NF-кB by inflammatory or proliferative stimuli has been demonstrated in cultures of monocyte/macrophages, endothelial cells, smooth muscle cells, and T cells using electrophoretic mobility shift assays $(4,7,11,12)$. All of these cell types have been established as playing a key role in atherogenesis and display a distinct pattern of gene expression in this environment $(10,13)$. A variety of genes are induced in the atherosclerotic lesion that have been shown to be regulated by NF-кB proteins, including the genes encoding TNF- $\alpha$ $(4,10,14,15)$, IL-1 $\beta(10,16)$, macrophage colony-stimulating factor (M-CSF) $(4,17,18)$, GM-CSF $(4,10)$, monocyte chemotactic protein-1 $(4,19)$, tissue factor (TF) (20-23), vascular cell adhesion molecule-1 (24-26), intercellular adhesion molecule-1 (ICAM-1) $(4,27)$ and c-myc $(10,28)$. Some of these gene products such as TNF- $\alpha$ and IL- 1 are also able to activate NF- $\kappa$ B in vitro $(3,4)$. Recently, it has been demonstrated in cell culture experiments that minimally oxidized LDL, a potential etiologic agent for promoting lesion formation $(8,9)$ activates NF$\kappa \mathrm{B}$ in endothelial cells (29). Oxidized lipoproteins have also been shown to modulate the expression of several cytokines, growth factors, and LPS-induced molecules which are regulated by NF-кB transcriptional proteins (30-35).

The presented study was designed to elucidate the role of $\mathrm{NF}-\kappa \mathrm{B} / \mathrm{Rel}$ transcription factors in the pathogenesis of human atherosclerosis. The activation of NF- $\mathrm{KB}$ is regulated at a posttranslational level and, therefore, cannot be directly monitored by detection of new mRNA or protein (3-7). Recently, a mouse $\mathrm{mAb}$, designated $\alpha$-p65mAb, was developed that recognizes an epitope on the p65 subunit that is masked by bound IкB (36-38). This antibody exclusively detects activated NF$\kappa \mathrm{B}$ because it recognizes p65 only in the absence of $\mathrm{I} \mathrm{B}$. The $\alpha-p 65 \mathrm{mAb}$ antibody allows the investigation of the activation state of $\mathrm{NF}-\kappa \mathrm{B}$ by immunofluorescence and immunohistochemical techniques at the single cell level in tissue sections

1. Abbreviations used in this paper: BDHC, benzidine dihydrochloride; DAB, 3-3'-diaminobenzidine; EMSA, electrophoretic mobility shift assay; HE, hematoxylin/eosin; ICAM-1, intercellular adhesion molecule-1; NF-кB, nuclear factor-kappa B; TF, tissue factor. 
and is therefore suitable for analysis of the in vivo situation at a cellular level. Tissue sections for the experiments consisted of cryosections from autopsies or endatherectomies displaying atherosclerosis (8-10). This study demonstrates the presence of activated NF- $\mathrm{B}$ transcription factor in the human atherosclerotic lesion in smooth muscle cells, macrophages, and endothelial cells.

\section{Methods}

Monoclonal antibody $\alpha-p 65 m A b$. Production and characteristics of the $\mathrm{mAb} \alpha-\mathrm{p} 65 \mathrm{mAb}$ are described elsewhere (36-38). The antibody $\alpha-$ p65Mab can be obtained from Boehringer Mannheim (Mannheim, Germany). This antibody allows the exclusive identification of active NF-кB.

Antibodies used for colocalization studies. The following monoclonal mouse antibodies were used: anti-human $\alpha$-smooth muscle actin (Dako, Hamburg, Germany), anti-human macrophage CD68 (Dako), anti-human T cell CD3 (Dako), anti-human vWf (Dako), anti-human TF (American Diagnostica Inc., Greenwich, CT), and anti-human ICAM-1 (CD54) (Dako).

Cryostat sections. Atherosclerotic tissue and specimens from normal aorta and arteries without atherosclerosis and veins were obtained from autopsies and endatherectomies. Tissue specimens were immediately frozen in a cryostat where the samples were protected by embedding media (Jung, Munich, Germany). 5- $\mu \mathrm{m}$ sections were cut and mounted onto poly-L-lysine (Sigma Chemical Co., St. Louis, $\mathrm{MO}$ ) coated slides, and stored at $-70^{\circ} \mathrm{C}$ before staining. All procedures were approved by the Ethical Committee of the Technical University, Munich, Germany.

Immunofluorescence. Immunofluorescence was performed essentially as described earlier (36-38). Briefly, sections were thawed and fixed in acetone for $10 \mathrm{~min}$ at $-20^{\circ} \mathrm{C}$. The tissue was rehydrated in $0.1 \mathrm{M}$ PBS for $5 \mathrm{~min}$ and unspecific binding was blocked with $1 \%$ BSA. The specimens were then incubated with the primary antibody or an isotype control (Sigma Chemical Co.) at $37^{\circ} \mathrm{C}$ for $1 \mathrm{~h}$ or overnight at $4^{\circ} \mathrm{C}$. The sections were washed twice in $0.1 \mathrm{M}$ PBS for $5 \mathrm{~min}$ followed by incubation with a biotinylated antiisotype antibody (Dianova, Hamburg, Germany) (30 min, room temperature). Again, the sections were washed twice and incubated with streptavidin-Cy3 (Dianova) (30 min, room temperature). After washing twice, the sections were covered with 10:1 glycerol/PBS buffer. Microphotographs were taken on a Leitz DMR photomicroscope (Leica, Wetzlar, Germany) equipped with epifluorescence optics. To be able to distinguish between the red Cy3 fluorescence (absorption: $550 \mathrm{~nm}$, emission 575 $\mathrm{nm})$ and the autofluorescence of the fibrotic tissue in the atherosclerotic lesion, the $G / R$ filter system (excitation filter: 490/20 nm, dichroitic mirror: 505, band pass filter: $525 / 20 \mathrm{~nm}$ ) from Leica was used (Brand, K. manuscript in preparation). After immunofluorescence, the sections were stained with hematoxylin/eosin (HE).

Immunohistochemistry. An immunohistochemical procedure for sequential double antigen localization was applied with minor modifications (39). The frozen sections were thawed, and the tissue was fixed in $3.7 \%$ buffered formaldehyde $(5 \mathrm{~min}$ ) followed by acetone $(50,100$, and $50 \% ; 2$ min each). Then, sections were rehydrated in 0.1 $\mathrm{M}$ PBS for $5 \mathrm{~min}$, and unspecific binding was blocked with $1 \%$ BSA. Incubation with the primary antibody was performed overnight at $4^{\circ} \mathrm{C}$. The sections were washed twice in $0.1 \mathrm{M}$ PBS and incubated with the biotinylated secondary antibody (Dianova) at room temperature for $1 \mathrm{~h}$. After washing, the tissue was incubated with the streptavidin biotin peroxidase complex (Zymed Laboratories, Inc., San Francisco, CA) at room temperature for $1 \mathrm{~h}$, washed again, and incubated in $0.03 \% \mathrm{wt} / \mathrm{vol} 3-3^{\prime}$ diaminobenzidine (DAB) (Sigma Chemical Co.) with $0.003 \% \mathrm{vol} / \mathrm{vol}$ hydrogen peroxide until a brown reaction product could be seen. To suppress any remaining peroxidase, the slides were incubated in $3 \%$ hydrogen peroxide for $30 \mathrm{~min}$. After washing three times, the sections were incubated with the second incubation series consisting of primary and secondary antibodies and streptavidin biotin peroxidase complex exactly as described above. Sections were washed extensively and preincubated for $10 \mathrm{~min}$ in $0.01 \%$ benzidine dihydrochloride (BDHC) (Sigma) with $0.03 \%$ sodium nitroprusside (Sigma). This was followed by incubation in the reaction medium ( $0.01 \%$ BDHC, $0.005 \%$ hydrogen peroxide, $0.03 \%$ sodium nitroprusside) for the second staining. The formation of the dark blue, granular reaction product was monitored under the light microscope. Afterwards, the sections were dehydrated and mounted in DePex (Fluka, Buchs, Germany). In some experiments, activated NF-кB was detected using $\alpha-$ p65mAb and BDHC and the first DAB step was omitted. In this case the tissue was counterstained with eosin. A series of control experiments was performed as described in Results.

Electrophoretic mobility shift assay (EMSA). Nuclear extracts from arterial tissue which was dissociated using a pestle and mortar were prepared and analyzed as previously described (22). Protein concentrations were determined by the Bradford method (Bio-Rad Laboratories, Hercules, CA). The prototypic double-stranded Ig kappachain oligonucleotide (5'-CAGAGGGACTTTCCGAGA-3') (4) was used as a probe and labeled by annealing of complementary primers followed by primer extension with the Klenow fragment of DNA polymerase I (Boehringer Mannheim) in the presence of $\left[\alpha-{ }^{32} \mathrm{P}\right] \mathrm{dCTP}$ (> 3,000 Ci/mmol; DuPont, Bad Homburg, Germany) and deoxynucleoside triphosphates (Boehringer Mannheim). Nuclear extracts (5 $\mu \mathrm{g}$ protein) were incubated with radiolabeled DNA probes $(\sim 10 \mathrm{ng}$; $10^{5} \mathrm{cpm}$ ) for $30 \mathrm{~min}$ at room temperature in $20 \mu \mathrm{l}$ of binding buffer (20 mM Tris- $\mathrm{HCl}, \mathrm{pH} 7.9 ; 50 \mathrm{mM} \mathrm{KCl} ; 1 \mathrm{mM}$ dithiothreitol; $0.5 \mathrm{mM}$ EDTA; $5 \%$ glycerol; $1 \mathrm{mg} / \mathrm{ml} \mathrm{BSA} ; 0.2 \% \mathrm{NP}-40 ; 50 \mathrm{ng} / \mu \mathrm{l}$ of poly[dI$\mathrm{dC})$. Samples were run in $0.25 \times$ TBE buffer $(10 \times$ TBE: $890 \mathrm{mM}$ Tris; $890 \mathrm{mM}$ boric acid; $20 \mathrm{mM}$ EDTA, $\mathrm{pH}$ 8.0) with loading dye on nondenaturing 4 or $6 \%$ polyacrylamide gels at $125 \mathrm{~V}$, for 1 or $3 \mathrm{~h}$, respectively. As a control, samples were incubated with an excess $(10 \times$, $100 \times$ ) of nonlabeled Igк-oligonucleotide that completely abolished binding. For supershift analysis the samples were incubated with antip50, anti-p65, and anti-c-rel rabbit polyclonal antibodies (Santa Cruz Biotechnology, Santa Cruz, CA). In addition, the nuclear extracts were incubated with a blunt end double-stranded Sp-1 oligonucleotide (GelShift assay kit; Stratagene Inc., La Jolla, CA) which was labeled with $\left[\gamma^{-32} \mathrm{P}\right]$ ATP $(>5,000 \mathrm{Ci} / \mathrm{mmol}$; DuPont, Bad Homburg, Germany) and T4 polynucleotide kinase (Boehringer Mannheim). Gels were dried and analyzed by autoradiography.

\section{Results}

Patients. The cryostat sections that we used for our experiments were obtained from autopsies or endatherectomies. Representative cases of patients with atherosclerosis are listed in Table I together with the clinical status or cause of death of each individual. The age of the patients ranged from 42 to 81 yr ( 8 female, 10 male). None of the patients suffered from any

Table I. Clinical Status or Cause of Death in Subjects with Atherosclerosis

\begin{tabular}{rlc}
\hline $\begin{array}{c}\text { No. of } \\
\text { cases }\end{array}$ & \multicolumn{1}{c}{ Clinical status or cause of death } & Source \\
\hline 1 & Bleeding of esophageal varicosis & A \\
1 & Fulminant lung emboly & A \\
1 & Chronic obstructive lung disease, lung emboly & A \\
1 & Cardiac failure due to infarction & A \\
3 & Aortic dissection & E \\
10 & Stenosis of carotid artery & E \\
1 & Stenosis of renal artery, hypertension & E
\end{tabular}

A, autopsy, E, endatherectomy. 

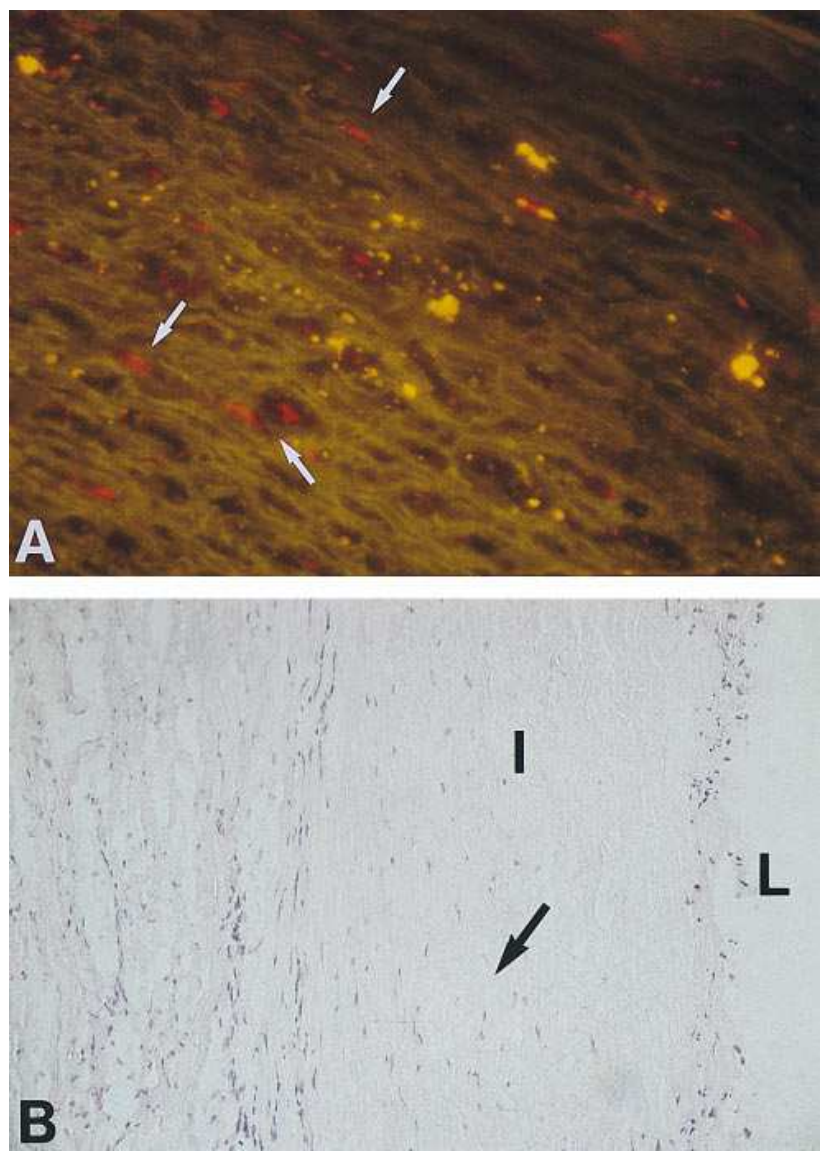

Figure 1. Presence of activated NF-кB transcription factor in the fibrotic thickened intima close to the media in an advanced atherosclerotic lesion. $(A)$ The red Cy3 fluorescence indicates activated NF-кB (white arrows) that was detected by indirect immunofluorescence techniques using the monoclonal antibody $\alpha$-p65mAb (dilution 1:34). The fibrotic tissue of the intima causes an intensive green-yellow autofluorescence. $\times 150$. (B) HE staining demonstrates the presence of loosely scattered cells in the fibrotic thickened intima $(I)$. The area shown in $A$ is indicated by the arrow. $L$, lumen. $\times 60$.

severe infectious disease which might induce or alter the activation of NF- $\mathrm{kB}$ in the vessel wall at the time the sections were obtained. For the presented study, unless otherwise stated, typical advanced atherosclerotic lesions with fibrous and fibrofatty plaques and atheromatous areas with occasional calcification were selected from aorta and coronary, carotid and renal arteries. In some of the experiments, tissue with less advanced atherosclerosis still displaying an intact endothelial layer was examined.

Presence of activated NF- $k B$ in the atherosclerotic lesion. To detect activated NF- $\mathrm{KB}$ in atherosclerotic lesions, indirect immunofluorescence techniques were applied together with the G/R detection filter system (see Methods). Activated NF$\kappa \mathrm{B}$, indicated by red fluorescence (Cy3), was identified in the fibrotic thickened intima/media of the advanced atherosclerotic lesion (Fig. $1 A$ ). In addition, a strong green-yellow autofluorescence of the fibrotic tissue was observed (Fig. 1A). The yellow spots may be due to autofluorescence of deposits accumulating during atherogenesis (e.g., extracellular matrix products) since they were not observed in normal tissue as will be shown below. HE staining demonstrated the presence of loosely scattered cells throughout this region (Fig. 1B). A high
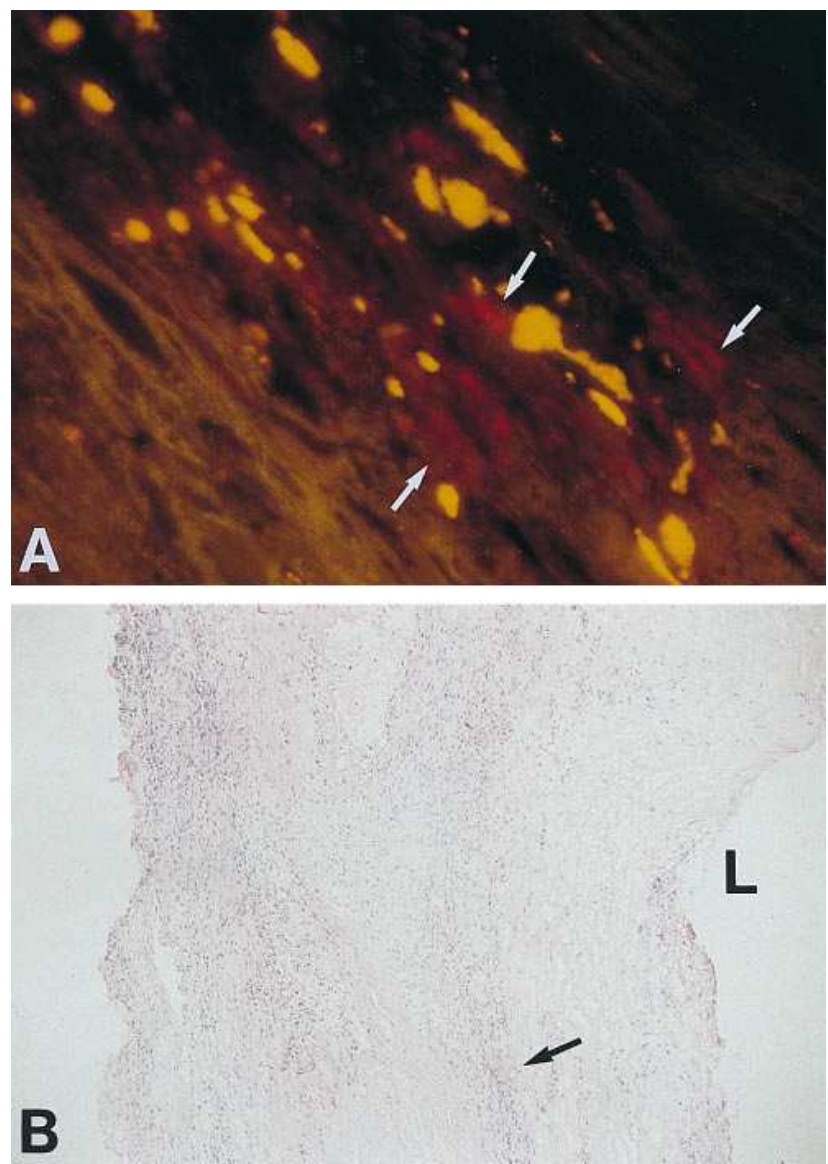

Figure 2. Activation of NF- $\mathrm{kB}$ in the atheromatous region of an advanced atherosclerotic lesion. (A) Activated NF-кB (white arrows) was detected using $\mathrm{Cy} 3$ (red fluorescence) as indicated in legend to Fig. 1. Autofluorescence of the fibrotic tissue was observed as described in the previous figure. $\times 160$. (B) HE staining of the atheromatous area of an advanced lesion. The region depicted in $A$ is demonstrated by the arrow. $L$, lumen. $\times 20$.

number of cells displaying activated NF-kB could also be found in atheromatous areas of the atherosclerotic vessel (Fig. $2 A$ ). An overview of this region is depicted in Fig. $2 B$, which displays a significant accumulation of cells as determined by HE staining. Essentially, the same results were obtained with immunofluorescence techniques in material from autopsies (Figs. 1 and 2) or endatherectomies (data not shown). No NF$\kappa \mathrm{B}$ signal was detected using an unspecific isotype control antibody (mouse IgG3) (Fig. $3 A$ ), in the absence of the primary antibody or when only streptavidin-Cy3 without the primary or secondary antibody was added (data not shown).

Identification of cell types in the atherosclerotic lesion displaying activated $N F-\kappa B$. The cell types in which NF- $\kappa$ B was activated in the atherosclerotic lesion were identified by an immunohistochemical procedure for sequential double antigen localization using DAB and BDHC (39). It has been demonstrated for this technique that there is no color mixing or antibody cross reaction (39). The antibodies for the identification of cell types were used for the first staining step which was visualized with $\mathrm{DAB}$ (diffuse brown reaction product). $\mathrm{DAB}$ staining was prevented when the primary antibody for the first step was omitted or replaced by an isotype control antibody or when $\mathrm{DAB}$ alone without primary and secondary antibody 

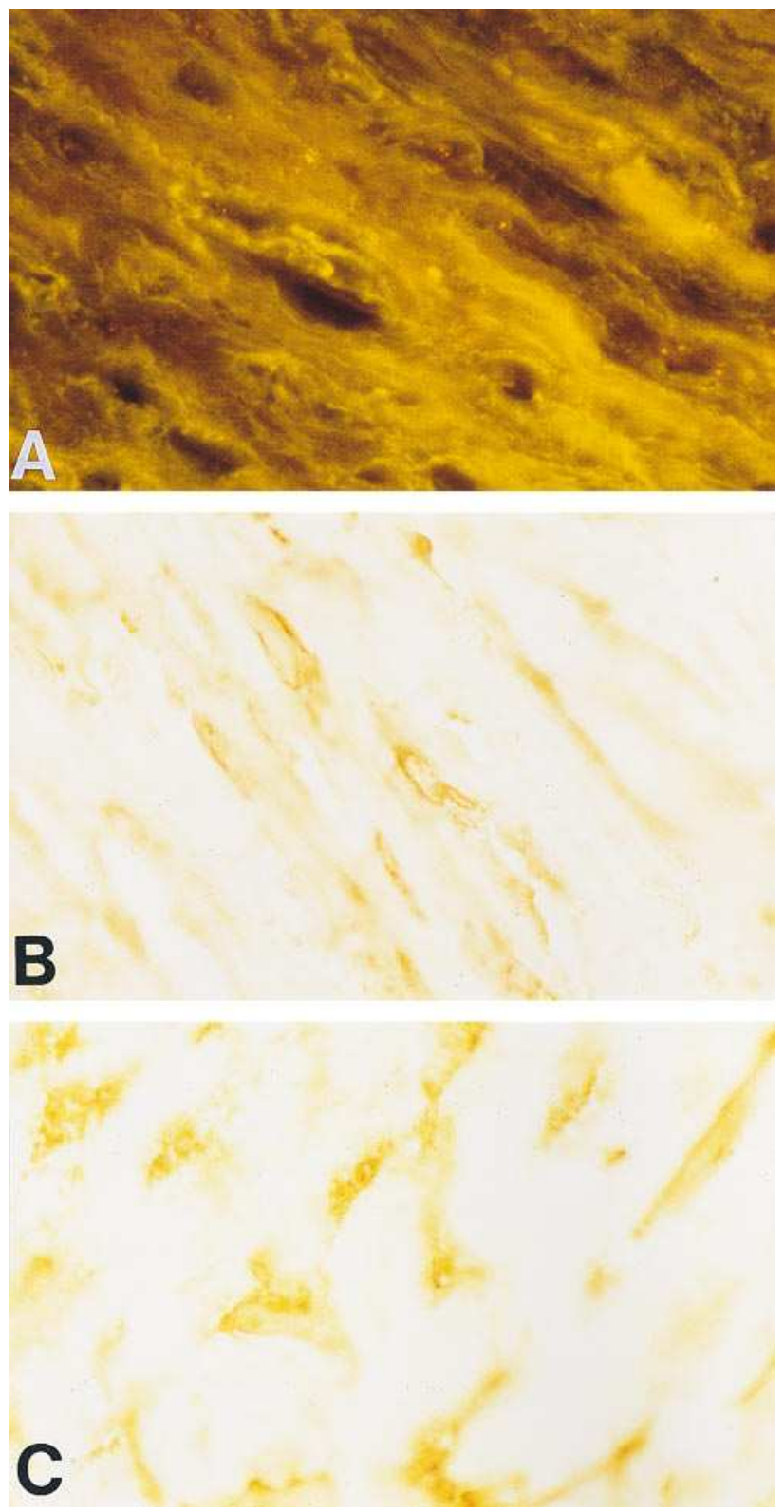

Figure 3. Controls for immunofluorescence and immunohistochemistry using sections from atherosclerotic tissue. $(A)$ Isotype control for immunofluorescence. The primary $\alpha-p 65 \mathrm{mAb}$ antibody was omitted and replaced by a mouse $\operatorname{IgG} 3$ isotype control antibody. A strong green-yellow autofluorescence of the fibrotic tissue was observed but no specific Cy3 labeling. $\times 180$. (B) Isotype control for immunohistochemistry. Antibodies against $\alpha$-actin (dilution 1:200) and DAB staining were used to identify smooth muscle cells (diffuse brown spindle shaped staining). The primary $\alpha-\mathrm{p} 65 \mathrm{mAb}$ antibody for the second BDHC staining step was omitted and replaced by a mouse isotype control antibody (IgG3). $\times 290$. (C) Substrate control for immunohistochemistry. CD68 antibodies (dilution 1:1000) and DAB staining (diffuse brown reaction product) were used to detect macrophages. The primary and secondary antibodies were omitted during the second step and the section incubated with BDHC alone. $\times 460$. Neither immunohistochemical control section $(B$ or $C$ ) exhibited specific labeling with BDHC.
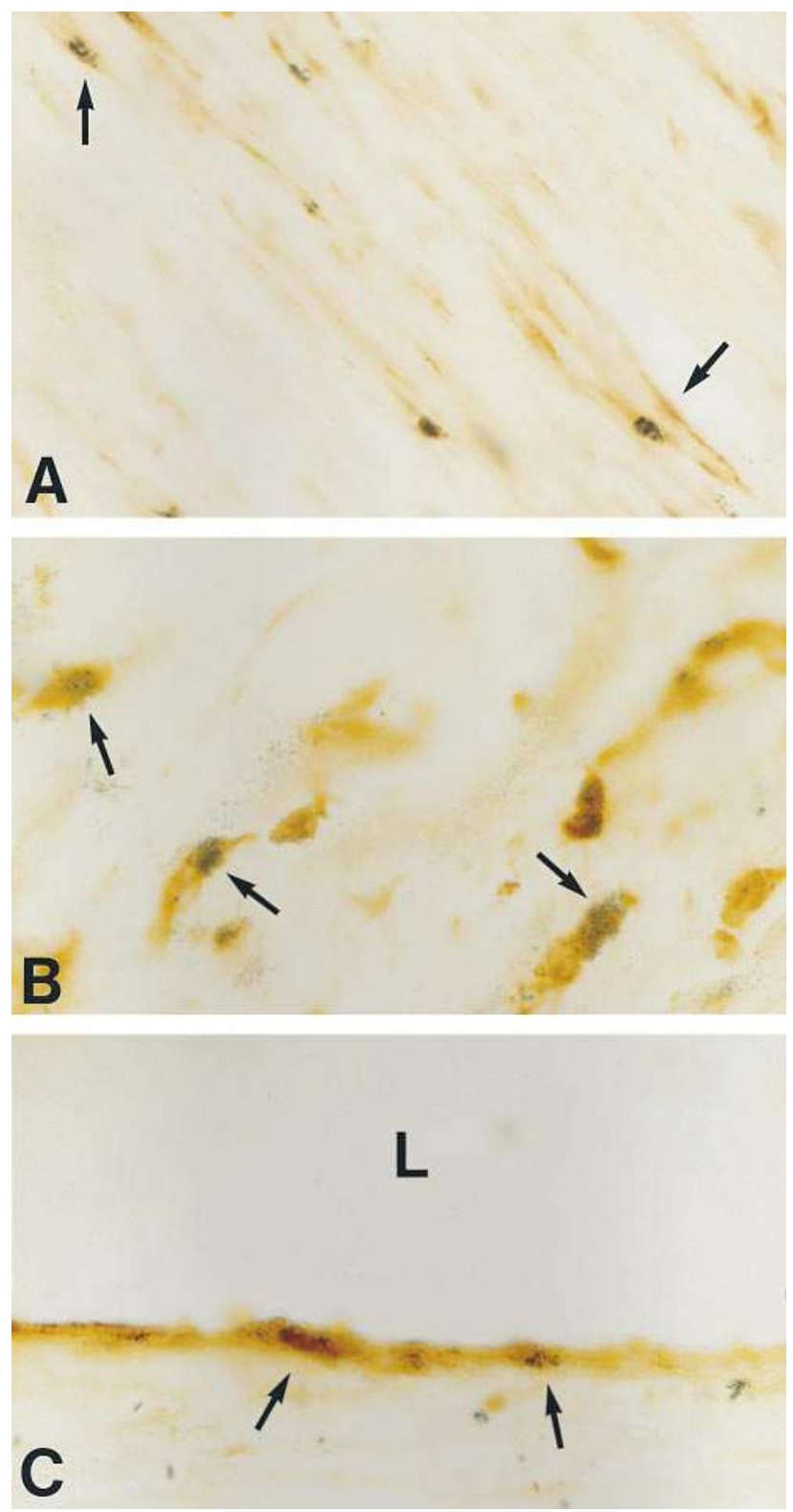

Figure 4. Localization of activated NF- $\mathrm{KB}$ in smooth muscle cells, macrophages, and endothelial cells in the atherosclerotic lesion. The specimens were obtained by endatherectomy from atherosclerotic lesions in the carotid artery $(A$ and $B)$ and aorta $(C)$. An immunohistochemical procedure for sequential double antigen localization with $\mathrm{DAB}$ and BDHC was applied. $(A)$ Activation of NF- $\mathrm{KB}$ in smooth muscle cells. Antibodies against $\alpha$-actin (dilution 1:200) and DAB staining were used to identify smooth muscle cells. A diffuse brown spindle-shaped staining fills most of the cellular area. Activated NF$\kappa \mathrm{B}$ was identified by $\alpha-\mathrm{p} 65 \mathrm{mAb}$ (dilution 1:500) and BDHC staining, giving a dark blue-color and a more granular staining pattern. Cells displaying a significant activation of NF- $\mathrm{KB}$ are indicated by the arrows. Activated NF- $\mathrm{KB}$ appears to be present mostly in the nucleus of the cells. $\times 270$. (B) Macrophages display activated NF- $\kappa$ B. Anti CD68 antibodies (dilution 1:1000) and DAB staining were used to identify macrophages. Activated NF- $\mathrm{KB}$ was detected as described in $A$. Cells displaying a significant activation of NF- $\mathrm{BB}$ are indicated by arrows. $\times 430$. (C) NF- $\kappa \mathrm{B}$ activation in endothelial cells. Antibodies against $\mathrm{vWf}$ (dilution 1:50) and DAB staining were applied to detect endothelial cells. Activated NF- $\mathrm{B}$ was detected as described in $A$. Cells displaying activated NF-кB are indicated by arrows. $L$, lumen. $\times 270$. 
was added (data not shown). The $\alpha-p 65 \mathrm{mAb}$ was applied for the second staining step with BDHC to detect activated NF$\kappa \mathrm{B}$ as will be shown below. The BDHC deposit is dark blue and granular and therefore easily distinguishable from the $\mathrm{DAB}$ reaction product. No BDHC staining was seen in control experiments in which the primary antibody for the second BDHC step $(\alpha-p 65 \mathrm{mAb})$ was replaced by an isotype control (mouse IgG3) (Fig. $3 \mathrm{~B}$ ), omitted (data not shown), or when $\mathrm{BDHC}$ alone was added without the primary and secondary antibody incubations for the second staining step (Fig. 3C) after detection of the first antigen.

Using cell-specific antibodies, the presence of a large number of smooth muscle cells and macrophages and to a lesser extent $\mathrm{T}$ cells was identified in the advanced atherosclerotic lesions which we examined in this study. This is consistent with earlier reports which identified smooth muscle cells and macrophages as the most prominent cell types in the advanced atherosclerotic lesion (13). Activated NF- $\mathrm{kB}$ could be detected in both smooth muscle cells (Fig. $4 A$ ) and macrophages (Fig. 4 $B)$ in the atherosclerotic lesions that were examined. Staining with $\alpha-p 65 \mathrm{mAb}$ was more localized within the cell and showed a different pattern than that obtained with the cell-specific antibodies used for the first staining step. The staining pattern of $\alpha-p 65 \mathrm{mAb}$ is consistent with earlier results which indicate that most of the activated NF- $\mathrm{B}$ is present in the nucleus (36-38). In addition, some of the $\mathrm{T}$ cells observed in the atherosclerotic lesions showed a faint signal for activated NF- $\mathrm{B}$ (data not shown) that appeared far below the level observed in smooth muscle cells and macrophages. A comparable low level of NF$\kappa \mathrm{B}$ activation in $\mathrm{T}$ cells attracted to sites of inflammation has been described earlier (37).

In addition, it should be mentioned that the greater part of the endothelial barrier has been destroyed or at least altered (vascular injury type II or III with endothelial denudation) (40, 41 ) in the advanced atherosclerotic regions that we used in our investigations. Therefore, to examine NF- $\mathrm{B}$ activation in endothelial cells, cryostat sections were made from tissue with less advanced atherosclerosis, hence still displaying a rather intact endothelial layer. An antibody against vWf that marks endothelial cells was used for the first staining step with DAB. Activated NF-кB was detected in the second staining with $\alpha$-p65mAb and BDHC. Fig. $4 C$ demonstrates the presence of activated NF- $\mathrm{KB}$ in endothelial cells in atherosclerotic tissue.

Little or no $N F-\kappa B$ activation is present in normal vessels without atherosclerosis. Cryostat sections were obtained from tissue taken from normal aorta or arteries without atherosclerosis (nine individuals) and from superficial veins of the lower extremity (one individual). The sections from vessels without atherosclerosis were incubated as described above using immunofluorescence and immunohistochemical techniques. The data using immunofluorescence are depicted in Fig. $5 \mathrm{~A}$, which demonstrates little or no activation of NF- $\mathrm{KB}$ in the intima/ media region of normal arterial tissue without atherosclerosis. Similar results were obtained when immunohistochemical staining was applied. In this case, the tissue from normal aorta and arteries was incubated with $\alpha-\mathrm{p} 65 \mathrm{mAb}$ and BDHC followed by eosin staining to visualize the tissue (Fig. $5 \mathrm{~B}$ ) or cellspecific markers (DAB) followed by $\alpha$-p65mAb (BDHC) (data not shown). Again, little or no activated NF-кB could be detected in normal arterial tissue lacking atherosclerosis. As an additional control, tissue from veins was examined in which no apparent NF-кB activation was observed (Fig. 5 C).
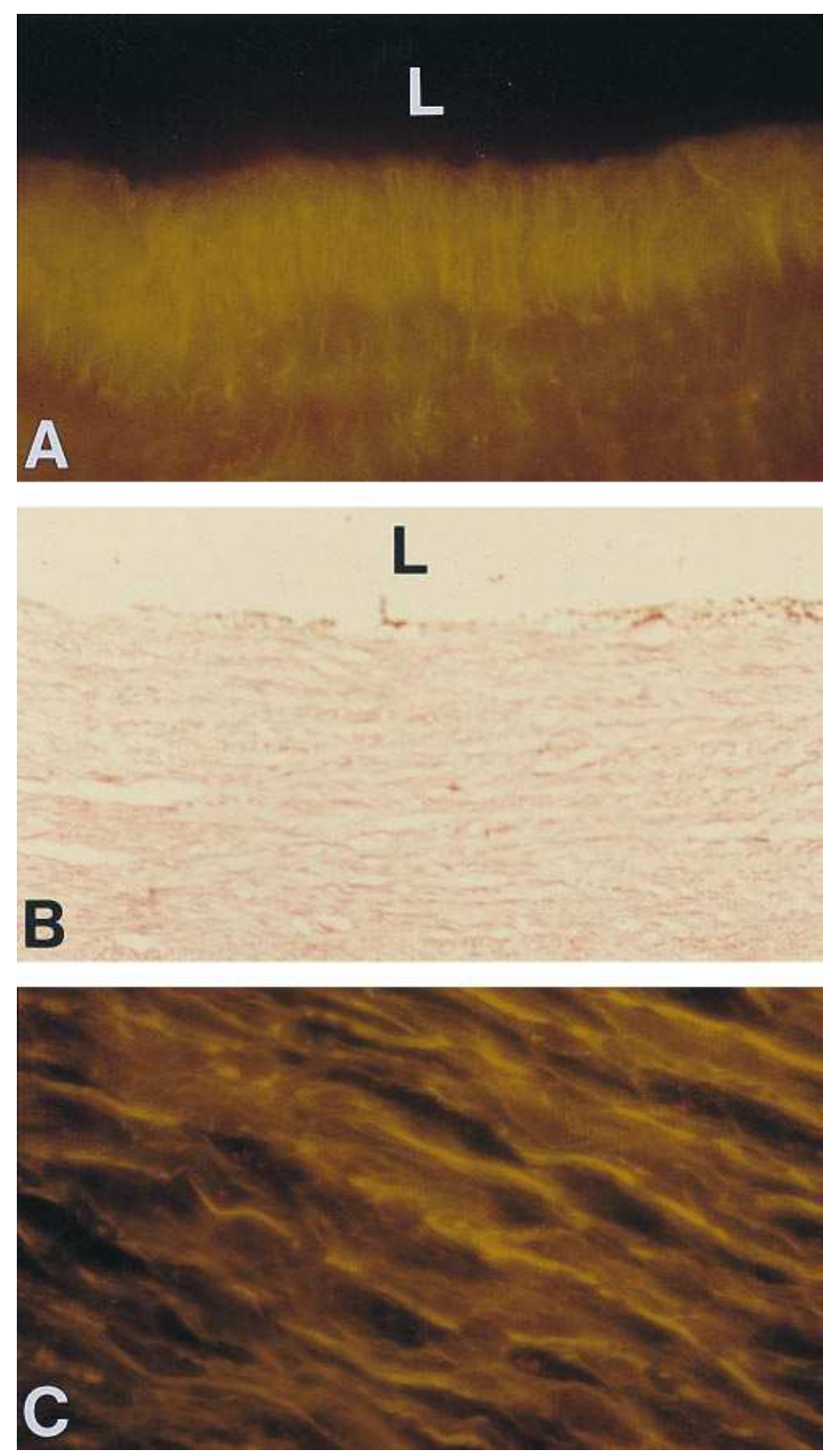

Figure 5. Little or no activated NF-кB is present in normal aorta and arteries without atherosclerosis and in veins. $(A)$ Normal arteries were investigated by immunofluorescence as described in Figs. 1 and 2. A faint yellow autofluorescence of the blood vessel was found but no active NF-кB was detectable. $\times 170$. (B) Immunohistochemical staining of normal aorta. No apparent activation of NF-кB was identified using $\alpha-p 65 \mathrm{mAb}$ (dilution 1:500) and BDHC. The tissue was counterstained with eosin. Note that there are some erythrocytes sticking to the luminal surface of the vessel. $\times 80$. (C) Venous tissue was analyzed by immunofluorescence. A yellow autofluorescence of the tissue can be seen. $\times 170$.

Functional implications of activated $N F-\kappa B$ in the atherosclerotic lesion. The presence of activated NF- $\mathrm{B}$ in the atherosclerotic lesion was also investigated by EMSA, examining the DNA binding activity of nuclear proteins to an NF- $\mathrm{KB}-$ specific oligonucleotide. Nuclear extracts were isolated from normal arterial tissue without atherosclerosis and aorta and arteries displaying atherosclerosis. The experiments with EMSA demonstrated an increased level of activated NF- $\mathrm{KB}$ in atherosclerotic lesions compared to nonatherosclerotic tissue (Fig. 6 A) which confirms our data obtained with immunofluorescence and immunohistochemical techniques. Identity of the $\mathrm{NF}-\kappa \mathrm{B}$ bands was established by competition studies and su- 


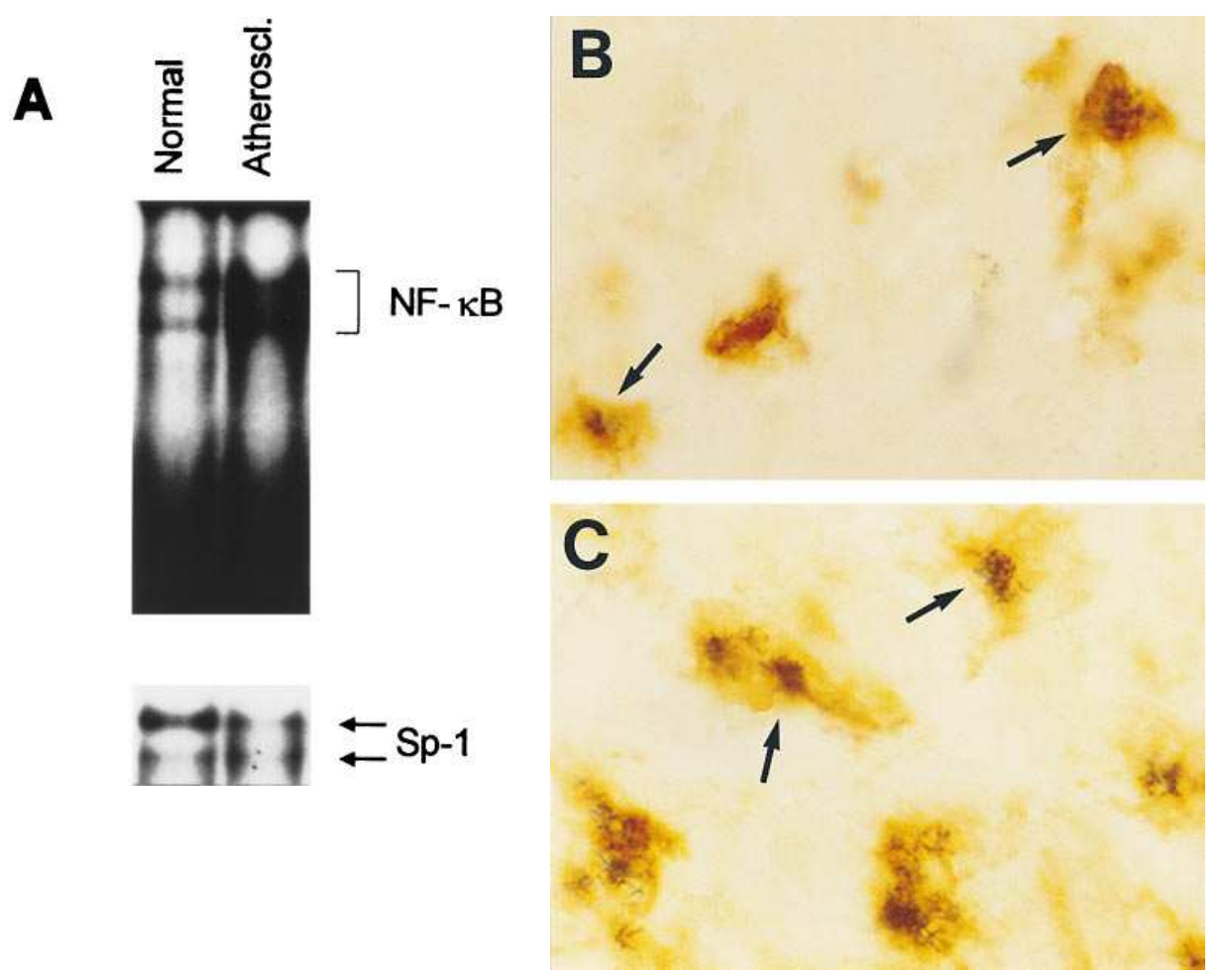

Figure 6. Functional implications of activated NF-кB in the atherosclerotic lesion. ( $A$ ) DNA binding activity of nuclear proteins to an NF-кB-specific oligonucleotide. Nuclear extracts were isolated from normal arteries without atherosclerosis (Normal) and arteries displaying atherosclerosis (Atheroscl.) and analyzed by EMSA. The brackets indicate activated NF$\kappa \mathrm{B}$. Binding of nuclear proteins to an oligonucleotide containing the Sp-1 consensus sequence was also examined by EMSA in the same nuclear extracts (double arrow). The EMSA autoradiograph shown is representative of three independent experiments. (B) Colocalization of activated NF- $\kappa \mathrm{B}$ with the expression of the NF$\kappa \mathrm{B} /$ Rel target gene TF. Immunohistochemical methods were used as described in legend to Fig. 4. TF (antibody dilution 1:200) was identified in the first staining step with DAB, activated $\mathrm{NF}-\kappa \mathrm{B}$ in the second step with BDHC. Cells displaying activated NF$\kappa \mathrm{B}$ are indicated by arrows. $\times 590 .(C)$ Colocalization of NF- $\mathrm{kB}$ activation with ICAM-1 expression (antibody dilution 1:200). Immunohistochemical staining procedure and magnification is described in $B$.

pershift analysis (data not shown). For the same extracts, we also examined the binding of nuclear proteins to an oligonucleotide comprising the Sp-1 consensus sequence. This showed that nuclear extracts were all of the same quality and approximate concentration (Fig. $6 A$ ).

To test if the active NF-кB in the atherosclerotic lesion has functional implications for gene expression, we examined the colocalization of the activated state of this transcription factor with the expression of the established $\mathrm{NF}-\kappa \mathrm{B} / \mathrm{Rel}$ target genes, TF (20-23) and ICAM-1 (4, 27, 42). Immunohistochemical methods were used as described above. TF (Fig. $6 \mathrm{~B}$ ) and ICAM-1(Fig. $6 C$ ) were identified in the first staining step, activated NF-кB in the second step. Again, a centrally located $\mathrm{BDHC}$ reaction product indicating activated $\mathrm{NF}-\kappa \mathrm{B}$ was found similar to the pattern described in Fig. 4. Colocalization in the same cell of activated NF-кB with TF or ICAM-1 expression, respectively, indicates that this transcription factor is involved in gene expression in the atherosclerotic lesion.

\section{Discussion}

This study demonstrates for the first time the presence of activated $\mathrm{NF}-\kappa \mathrm{B}$ in the human atherosclerotic lesion using a newly developed antibody, $\alpha$-p65mAb, which allows the identification of the active state of this transcription factor (36-38). Activated NF-кB was found in the fibrotic thickened intima/media and atheromatous areas of the atherosclerotic lesion in both smooth muscle cells and macrophages. In addition, we identified activated NF-кB in endothelial cells in lesions with less advanced atherosclerosis. Our data were confirmed by EMSA which detected an increased level of activated NF-кB in the atherosclerotic tissue compared to normal tissue. The hypothesized central role of $\mathrm{NF}-\mathrm{KB} / \mathrm{Rel}$ in the pathogenesis of atherosclerosis is summarized in Fig. 7.

Numerous observations indicate that the smooth muscle cell changes from a contractile to a synthetic phenotype displaying fibroblast-like features during lesion formation (10). This cell type is the major source of connective tissue in the atherosclerotic lesion $(10,43)$. In the synthetic state, smooth muscle cells are capable of expressing genes that can be modulated by $\mathrm{NF}-\kappa \mathrm{B}$ in vitro, such as TNF- $\alpha$, IL-1, M-CSF, GMCSF, or monocyte chemotactic protein-1 (4, 10, 14, 16-18). The NF-кB involved in regulation of these genes may be activated by inflammatory cytokines or reactive oxygen intermediates all of which can be produced by smooth muscle cells themselves as well as by monocyte/macrophages, endothelial cells, or lymphocytes (4, 7-10). Increased activation of $\mathrm{NF} \kappa \mathrm{B}$ could even be triggered in an autocrine loop by NF- $\mathrm{kB}-$ induced TNF- $\alpha$ or IL-1 itself $(4,16)$. Activated NF- $\mathrm{BB}$ has been identified in our laboratory in cultured smooth muscle cells using electrophoretic mobility shift assays (Brand, K., unpublished observations). Additionally, two recent studies demonstrate NF-кB activation in cultured smooth muscle cells by fibronectin (12) and thrombin (44).

Macrophages represent the principal inflammatory cells in the atheromatous plaque microenvironment (8-10). During lesion formation, macrophages are in close contact with smooth muscle cells and endothelial cells and are involved in various processes including the phagocytosis of noxious materials accumulating in the vessel wall $(8,9)$. In addition, there is a close interaction between macrophages and T cells in the atherosclerotic lesion, indicating that some form of immune response is 


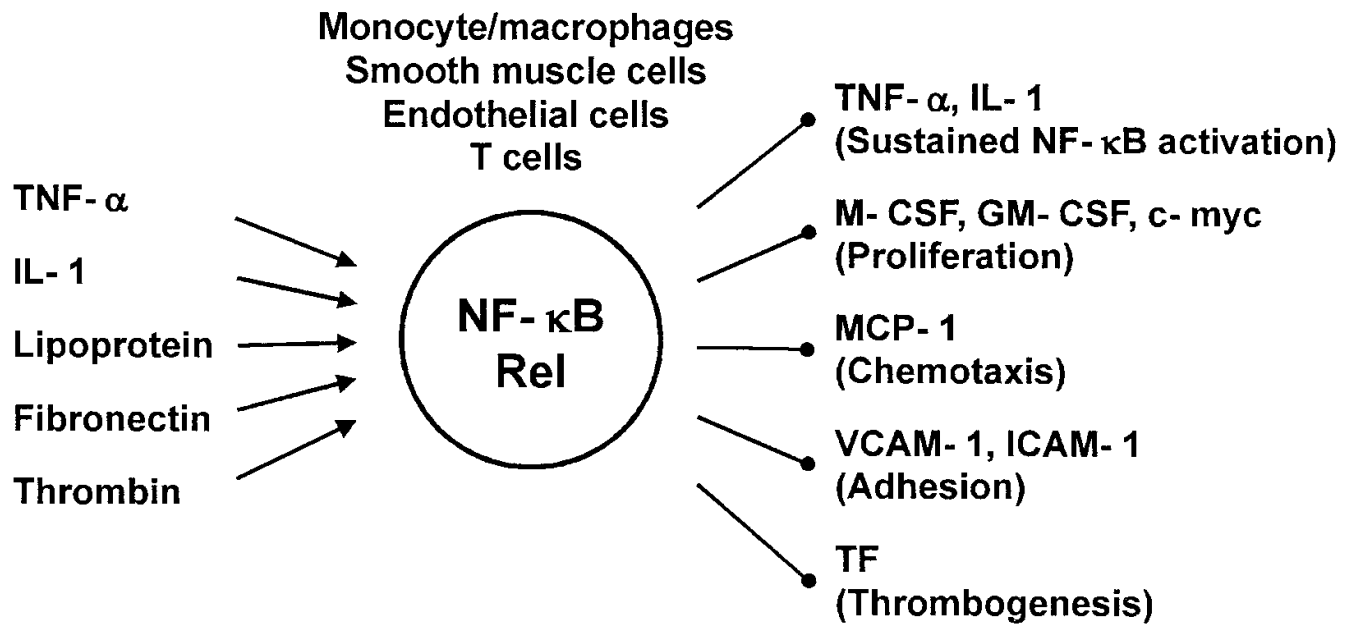

Figure 7. Model for the role of NF- $\mathrm{B} / \mathrm{Rel}$ transcription factors in the pathogenesis of atherosclerosis. Stimuli for $\mathrm{NF}-\kappa \mathrm{B} / \mathrm{Rel}$ activation in monocyte/macrophages, smooth muscle cells, endothelial cells, and $\mathrm{T}$ cells are listed on the left. Genes that may be regulated by NF-кB/ $\mathrm{Rel}$ in the atherosclerotic lesion are depicted on the right. Functional implications are indicated in parenthesis. The references are stated in the text. involved $(45,46)$. In this environment, it is suggested that macrophages express a variety of genes, e.g., cytokines $(4,8-10)$, TF (20-23), or ICAM-1 $(27,42)$, that are regulated by the NF$\kappa \mathrm{B}$ system in a fashion similar to that described above for smooth muscle cells. An additional NF-kB-activating agent may be oxidized lipoprotein, which has also been identified in vivo in the lesion $(8,9,29,30)$. Recent data from our laboratory indicate that lipoproteins directly induce NF- $\mathrm{kB}$ in cells of the monocytic lineage (Brand, K., unpublished observations). The dysregulation of transcriptional systems associated with the uncontrolled intracellular accumulation of lipids could be one of the molecular causes that lead to foam cell formation reported in macrophages $(8,9,47)$ and smooth muscle cells $(10)$.

Activated NF- $\mathrm{B}$ was also identified in endothelial cells in the atherosclerotic lesion in our experiments. It has been suggested that NF-кB activation in this cell type may play an important role in the pathogenesis of atherosclerosis $(11,29,30)$. The expression of several adhesion molecules involved in the interaction of blood cells with the endothelium such as ICAM-1, vascular cell adhesion molecule-1, or endothelial leukocyte adhesion molecule- 1 have been shown to be regulated by NF-kB in cell culture experiments $(4,11,24-27)$. This expression appears to be sensitive to certain antioxidants that are known to be potent inhibitors of NF-кB activation $(48,49)$. Furthermore, activated NF- $\mathrm{B}$ may modulate the endothelial cell production of chemotactic substances, such as monocyte chemotactic protein-1, that attract leukocytes to the lesion $(4,11,19)$.

The principal surgical approaches to the treatment of atherosclerosis-endatherectomy, percutaneous transluminal angioplasty, and bypass grafting - are associated with a high failure rate due to restenosis $(10,50)$. This reocclusion of the artery is probably caused by further inflammation, smooth muscle accumulation, and thrombosis $(50,51)$. The increased production of substances that trigger the occurrence of these surgical complications, such as cytokines, growth factors, or the highly thrombogenic molecule $\mathrm{TF}$, appears to be at least partly modulated by NF-кB (4, 8-10, 20-23), a molecule here demonstrated to be present in an activated state in tissue from endatherectomies. A colocalization of activated NF- $\mathrm{B}$ with the expression of the NF- $\mathrm{B} /$ Rel target gene TF in the same cell could be demonstrated in our experiments, indicating a functional role for this activated transcription factor in the atherosclerotic lesion. Therefore, the antibody $\alpha-p 65 \mathrm{mAb}$ applied in this study might be used as a prognostic tool to identify patients with a higher risk for thrombotic complications and restenosis.

It has been suggested that proteins of the NF-кB/Rel family play an important role in inflammation, immune response, and cell growth $(3,4)$. Atherogenesis, characterized by features of chronic inflammation and proliferative processes (8-10), may be a paradigm for the involvement of NF- $\mathrm{kB} / \mathrm{Rel}$ in human chronic inflammatory disease. Further studies are necessary to characterize the role of this complex regulatory system in human atherosclerosis.

\section{Acknowledgments}

We are very grateful to Dr. L.K. Curtiss, Dr. C.L. Banka, and Dr. N. Mackman (Research Institute of Scripps Clinic, La Jolla, CA) and to Prof. Dr. W. Nathrath (Institute of Pathology, Technical University Munich, Germany) for helpful discussion and to T. Eisele for technical assistance.

This work was supported by a grant from the Deutsche Forschungsgemeinschaft (Br 1026/3-1, Dr. K. Brand).

\section{References}

1. Lenardo, M.J., and D. Baltimore. 1989. NF-кB: a pleiotropic mediator of inducible and tissue-specific gene control. Cell. 58:227-229.

2. Baeuerle, P.A. 1991. The inducible transcription activator NF-кB: regulation by distinct protein subunits. Biochim. Biophys. Acta. 1072:63-80.

3. Grilli, M., J.J.-S. Chiu, and M.J. Lenardo. 1993. NF-кB and Rel: participants in a multiform transcriptional regulatory system. Int. Rev. Cytol. 143:1-62.

4. Baeuerle, P.A., and T. Henkel. 1994. Function and activation of NF-кB in the immune system. Annu. Rev. Immunol. 12:141-179.

5. Baeuerle, P.A., and D. Baltimore. 1988. IкB: a specific inhibitor of the NF-кB transcription factor. Science (Wash. DC). 242:540-546.

6. Cheng, Q., C.A. Cant, T. Moll, R. Hofer-Warbinek, E. Wagner, M.L. Birnstiel, F.H. Bach, and R. de Martin. 1994. NF-kappa B subunit-specific regulation of the I kappa B-alpha promoter. J. Biol. Chem. 296:13551-13557.

7. Müller, J.M., H.W.L. Ziegler-Heitbrock, and P.A. Baeuerle. 1993. Nuclear factor kappa B, a mediator of lipopolysaccharide effects. Immunobiology. 187: $233-256$.

8. Witztum, J.L., and D. Steinberg. 1991. Role of oxidized low density lipoprotein in atherogenesis. J. Clin. Invest. 88:1785-1792.

9. Berliner, J.A., M. Territo, A. Andalibi, M. Navab, F. Liao, S. Cushing, S. Imes, J. Kim, B. van Lenten, A.J. Lusis, and A.M. Fogelman. 1992. Modified li- 
poproteins and atherogenesis. In Cellular and Molecular Biology of Atherosclerosis. J.A.M. Gotto, editor. Springer-Verlag London Ltd., London. 77-80.

10. Ross, R. 1993. The pathogenesis of atherosclerosis: a perspective for the 1990s. Nature (Lond.). 362:801-809.

11. Collins, T. 1993. Endothelial nuclear factor-кB and the initiation of the atherosclerotic lesion. Lab. Invest. 68:499-508.

12. Qwarnström, E.E., C.O. Ostberg, G.L. Turk, C.A. Richardson, and K. Bomsztyk. 1994. Fibronectin attachment activates the NF-кB p50/p65 heterodimer in fibroblasts and smooth muscle cells. J. Biol. Chem. 269:3076530768.

13. Gown, A.M., T. Tsukada, and R. Ross. 1986. Human atherosclerosis. II. Immunocytochemical analysis of the cellular composition of human atherosclerotic lesions. Am. J. Pathol. 125:191-207.

14. Barath, P., M.C. Fishbein, J. Lao, J. Bernson, R.H. Helfaut, and J.S. Forrester. 1990. Tumor necrosis factor gene expression in human vascular smooth muscle cells detected by in vitro hybridization. Am. J. Pathol. 137:503509.

15. Beutler, B., and C. van Huffel. 1994. An evolutionary and functional approach to the TNF receptor/ligand family. Ann. NY Acad. Sci. 730:118-133.

16. Hiscott, J., J. Marois, J. Garoufalis, M. D'Addarion, A. Roulston, I. Kwan, N. Pepin, J. Lacoste, H. Nguyen, G. Bensi, and M. Fenton. 1993. Characterization of a functional NF-kappa B site in the human interleukin-1 $\beta$ promoter: evidence for a positive autoregulatory loop. Mol. Cell. Biol. 13:62316240.

17. Rosenfeld, M.E., S. Ylä-Herttuala, B.A. Lipton, V.A. Ord, J.L. Witztum, and D. Steinberg. 1992. Macrophage colony-stimmulating factor mRNA and protein in atherosclerotic lesions of rabbits and humans. Am. J. Pathol. 140: 291-300.

18. Clinton, S.K., R. Underwood, L. Haynes, M.L. Sherman, D.W. Kufe, and P. Libby. 1992. Macrophage colony-stimulating factor gene expression in vascular cells and in experimental and human atherosclerosis. Am. J. Pathol. 140:301-316

19. Ylä-Herttuala, S., B.A. Lipton, M.E. Rosenfeld, T. Särkioja, T. Yoshimura, E.J. Leonard, J.L. Witztum, and D. Steinberg. 1991. Expression of monocyte chemoattractant protein-1 in macrophage-rich areas of human and rabbit atherosclerotic lesions. Proc. Natl. Acad. Sci. USA. 88:5252-5256.

20. Wilcox, J.N., K.M. Smith, S.M. Schwartz, and D. Gordon. 1989. Localization of tissue factor in the normal vessel wall and in the atherosclerotic plaque. Proc. Natl. Acad. Sci. USA. 86:2839-2843.

21. Brand, K., B.J. Fowler, T.S. Edgington, and N. Mackman. 1991. Tissue factor mRNA in THP-1 monocytic cells is regulated at both transcriptional and posttranscriptional levels in response to lipopolysaccharide. Mol. Cell. Biol. 11: 4732-4738.

22. Mackman, N., K. Brand, and T.S. Edgington. 1991. Lipopolysaccharidemediated transcriptional activation of the human tissue factor gene in THP-1 monocytic cells requires both activator protein 1 and nuclear factor $\kappa \mathrm{B}$ binding sites. J. Exp. Med. 174:1517-1526.

23. Edgington, T.S., N. Mackman, K. Brand, and W. Ruf. 1994. The structural biology of expression and function of tissue factor. Thromb. Haemost. 66: $67-79$.

24. Cybulsky, M.I., and M.A. Gimbrone, Jr. 1991. Endothelial expression of a mononuclear leukocyte adhesion molecule during atherogenesis. Science (Wash. DC). 251:788-791.

25. Neish, A.S., A.J. Williams, H.J. Palmer, M.Z. Whitley, and T. Collins. 1992. Functional analysis of the human vascular cell adhesion molecule-1 promotor. J. Exp. Med. 176:1583-1593.

26. Iademarco, M.F., J.J. McQuillan, G.D. Rosen, and D.C. Dean. 1992. Characterization of the promotor for vascular cell adhesion molecule-1 (VCAM-1). J. Biol. Chem. 267:16323-16329.

27. Poston, R.N., D.O. Haskard, J.R. Coucher, N.P. Gall, and R.R. Johnson-Tidey. 1992. Expression of intercellular adhesion molecule-1 in atherosclerotic plaques. Am. J. Pathol. 140:665-673.

28. Duyao, M.P., A.J. Buckler, and G.E. Sonenshein. 1990. Interaction of an NF-кB like factor with a site upstream of the c-myc promotor. Proc. Natl. Acad. Sci. USA. 87:4727-4731.

29. Parhami, F., Z.T. Fang, A.M. Fogelman, A. Andalibi, M.C. Territo, and J.A. Berliner. 1993. Minimally modified low density lipoprotein-induced inflammatory responses in endothelial cells are mediated by cyclic adenosine monophosphate. J. Clin. Invest. 92:471-478.

30. Liao, F., A. Andalibi, J.-H. Qiao, H. Allayee, A.M. Fogelman, and A.J. Lusis. 1994. Genetic evidence for a common pathway mediating oxidative stress, inflammatory gene induction, and aortic fatty streak formation in mice. J. Clin. Invest. 94:877-884.

31. Rajavashisth, T.B., A. Andalibi, M.C. Territo, J.A. Berliner, M. Navab,
A.M. Fogelman, and A.J. Lusis. 1990. Induction of endothelial cell expression of granulocyte and macrophage colony-stimulating factors by modified low density lipoproteins. Nature (Lond.). 344:254-257.

32. Hamilton, T.A., G. Ma, and G.M. Chisholm. 1990. Oxidized low density lipoprotein suppresses the expression of tumor necrosis factor- $\alpha$ mRNA in stimulated murine peritoneal macrophages. J. Immunol. 144:2343-2350.

33. Fong, L.G., T.A.T. Fong, and A.D. Cooper. 1991. Inhibition of lipopolysaccharide-induced interleukin-1 $\beta$ mRNA expression in mouse macrophages by oxidized low density lipoprotein. J. Lipid Res. 32:1899-1910.

34. Brand, K., C.L. Banca, N. Mackman, R.A. Terkeltaub, S.T. Fan, and L.K. Curtiss. 1994. Oxidized low density lipoprotein enhances lipopolysaccharide-induced tissue factor expression in human adherent monocytes. Arterioscler. Thromb. 14:790-797.

35. Terkeltaub, R., C.L. Banca, J. Solan, D. Santoro, K. Brand, and L.K Curtiss. 1994. Oxidized LDL induces monocytic cell expression of interleukin8, a chemokine with T-lymphocyte chemotactic activity. Arterioscler. Thromb. 14:47-53.

36. Kaltschmidt, C., B. Kaltschmidt, H. Neumann, H. Wekerle, and P.A Baeuerle. 1994. Constitutive NF-кB activity in neurons. Mol. Cell. Biol. 14 3981-3992.

37. Kaltschmidt, C., B. Kaltschmidt, J. Lannes-Vieira, G.W. Kreutzberg, H. Wekerle, P.A. Baeuerle, and J. Gehrmann. 1994. Transcription factor NF-кB is activated in microglia during experimental autoimmune encephalomyelitis. $J$. Neuroimmunol. 55:99-106.

38. Kaltschmidt, C., B. Kaltschmidt, T. Henkel, H. Stockinger, and P.A. Baeuerle. 1995. Selective recognition of the activated form of transcription factor NF-кB by a monoclonal antibody. Biol. Chem. Hoppe-Seyler. 376:9-16.

39. Levey, A.I., J.P. Bolam, D.B. Rye, A.E. Hallanger, R.M. Demuth, M.-M. Mesulam, and B.H. Wainer. 1986. A light and electron microscopic procedure for sequential double antigen localization using diaminobenzidine and benzidine dihydrochloride. J. Histochem. Cytochem. 34:1449-1457.

40. Masuda, J., and R. Ross. 1990. Atherogenesis during low level hypercholesterolemia in the non human primate. II. Fatty streak conversion to fibrous plaque. Arteriosclerosis. 10:178-187.

41. Badimon, J.J., V. Fuster, J.H. Chesebro, and L. Badimon. 1993. Coronary atherosclerosis: a multifactorial disease. Circulation. 87:II3-II16.

42. Leenen, P.J., M.F. Bruijn, J.S. Voerman, P.A. Campbell, and W. Ewijk 1994. Markers of mouse macrophage development detected by monoclonal antibodies. J. Immunol. Methods. 174:5-19.

43. Amento, E.P., N. Ehsani, H. Palmer, and P. Libby. 1991. Cytokines and growth factors positively and negatively regulate interstitial collagen gene expression in human vascular smooth muscle cells. Arterioscler. Thromb. 11:1223 1230.

44. Nakajima, T., I. Kitajima, H. Shin, I. Takasaki, K. Shigeta, K. Abeyama, Y. Yamashita, T. Tokioka, Y. Soejima, and I. Maruyama. 1994. Involvement of NF-кB activation in thrombin-induced human vascular smooth muscle cell proliferation. Biochem. Biophys. Res. Commun. 204:950-955.

45. Libby, P., and G.K. Hansson. 1991. Involvement of the immune system in human atherogenesis: current knowledge and unanswered questions. $L a b$. Invest. 64:5-15.

46. Brand, K., N. Mackman, and L.K. Curtiss. 1993. Interferon- $\gamma$ inhibits macrophage apolipoprotein E production by posttranslational mechanisms. $J$. Clin. Invest. 91:2031-2039.

47. Wu, H., K. Moulton, A. Horvai, S. Parik, and C.K. Glass. 1994. Combinatorial interactions between AP-1 and ets domain proteins contribute to the developmental regulation of the macrophage scavenger receptor gene. Mol. Cell. Biol. 14:2129-2139.

48. Marui, N., M.K. Offermann, R. Swerlick, C. Kunsch, C.A. Rosen, M. Ahmad, R.W. Alexander, and R.M. Medford. 1993. Vascular cell adhesion molecule-1 (VCAM-1) gene transcription and expression are regulated through an antioxidant-sensitive mechanism in human vascular endothelial cells. J. Clin. Invest. 92:1866-1874.

49. Weber, C., W. Erl, A. Pietsch, M. Ströbel, H.W.L. Ziegler-Heitbrock, and P.C. Weber. 1994. Antioxidants inhibit monocyte adhesion by suppressing nuclear factor-к $\mathrm{B}$ mobilization and induction of vascular adhesion molecule-1 in endothelial cells stimulated to generate radicals. Arterioscler. Thromb. 14: $1665-1673$.

50. Ferrell, M., V. Fuster, H.K. Gold, and J.H. Chesebro. 1992. A dilemma for the 1990s choosing appropriate experimental animal model for the prevention of restenosis. Circulation. 85:1630-1631.

51. Dartsch, P.C., G. Bauriedel, I. Schinko, H.-D. Weiss, B. Höfling, and E. Betz. 1989. Cell constitution and characteristics of human atherosclerotic plaques selectively removed by percutaneus atherectomy. Atherosclerosis. 80: 149-157. 